\title{
A pilot study of the flipped classroom approach in higher education
}

\author{
Un estudio piloto de la clase invertida en educación universitaria \\ Alderantzizko eskolari buruzko ikerketa pilotua unibertsitateko \\ hezkuntzan
}

\author{
Encarnación Almazán Ruiz \\ Universidad de Jaén (España) \\ ealmazan@ujaen.es \\ https://orcid.org/0000-0001-8724-6596
}

\author{
Raquel Fuentes Martínez \\ Universidad de Jaén (España) \\ rfuentes@ujaen.es \\ https://orcid.org/0000-0003-1865-0864
}

\begin{abstract}
Teaching and learning grammar have become arduous tasks in the English classroom. On the one hand, students feel they are studying the same topics repeatedly. Teachers, on the other one, think students are not able to acquire the grammatical contents of the syllabus. As a direct consequence, it can be assumed it is high time to change the traditional methodology and introduce new approaches which allow us to involve students in their learning process. This paper is aimed at demonstrating the effectiveness of using the flipped classroom approach when teaching grammar. As it is a learner-centred model, students actively expose to contents at home and the in-class time is used to do tasks related to the previously worked contents. The instrument employed for this study is a questionnaire designed to know students' opinion about a flipped experience implemented in the English classroom. The results show that this teaching model can be a good option to avoid students' demotivation when teaching English grammar.
\end{abstract}

\section{Keywords}

Flipped classroom, teaching, learning, grammar, student-centred approach.

\section{Sumario}

1. Introduction. 2. Theoretical background 3. Methodology. 3.1. Research design. 3.2. The pilot experience. 4. DATA ANALYSIS AND FINDINGS. 4.1. Block 1: Students' opinion about the flipped approach. 4.2. Block 2: Students' opinion about cooperative learning. 4.3. Block 3: Students' impression about the experience. 5. Final CONSIDERATIONS ABOUt the FLIPPED EXPERIENCE. 6. LIMITATIONS AND FURTHER RESEARCH. 7. CONCLUSIONS. REFERENCES. 


\section{Resumen}

La enseñanza y el aprendizaje de la gramática inglesa se han convertido en tareas muy complejas dentro del aula. Mientras que el alumnado piensa que estudia los mismos temas repetidamente, los docentes, por otro lado, creen que los estudiantes no logran asimilar los contenidos. Como consecuencia, el introducir otros modelos basados en el alumno podría resultar ventajoso. Este artículo tiene como finalidad demostrar la efectividad del modelo de clase invertida a la hora de enseñar gramática. El alumnado se expone previamente de forma activa a los contenidos teóricos en casa, empleándose el tiempo de clase en realizar tareas relacionadas con los conceptos trabajados previamente. El instrumento empleado para este estudio es un cuestionario diseñado para conocer la opinión del alumnado sobre la experiencia con el modelo de la clase invertida. Los resultados demuestran que este modelo pedagógico puede ser una buena opción para evitar la desmotivación en el aula cuando se enseña gramática inglesa.

Palabras clave. Clase invertida, enseñanza, aprendizaje, gramática, modelo basado en el alumno.

\section{Laburpena}

Gramatika ingelesaren irakaskuntza eta ikaskuntza oso zeregin konplexuak bihurtu dira ikasgelan. Ikasleek uste dute gai berak behin eta berriz ikasten dituztela; eta irakasleek, berriz, ikasleek ez dituztela edukiak bereganatzen. Horren ondorioz, komenigarria izaten ahal da ikaslea oinarri duten beste eredu batzuk erabiltzea. Artikulu honen xedea da frogatzea alderantzizko eskolaren eredua eraginkorra dela gramatika irakasteko. Ikasleak etxean lantzen ditu aktiboki eduki teorikoak aldez aurretik, eta ikasgelako denbora aldez aurretik landutako kontzeptuekin zerikusia duten zereginetarako erabiltzen da. Azterketa honetarako baliatutako tresna galdetegi bat da, eta alderantzizko eskolaren ereduarekin izandako esperientziari buruz ikasleek nolako iritzia duten jakiteko balio du. Emaitzek erakusten dutenez, eredu pedagogiko hori aukera ona izan daiteke ikasleek motibazioa gal ez dezaten gramatika ingelesa irakasten zaienean.

Gako hitzak. Alderantzizko eskola, irakaskuntza, ikaskuntza, gramatika, ikaslean oinarritutako eredua.

\section{Introduction}

The teaching of grammar has been a theme of study for ages. Even though grammar is crucial when speaking and writing, the best way of explaining grammatical contents has not been found yet and teaching grammar has become an extremely difficult assignment in the English classroom. Teachers realise that the grammatical contents of the syllabus are not firmly acquired and, additionally, they have to play the role of motivators over and over again. On the other hand, students feel they are studying the same topics repeatedly, with the implied lack of motivation on their part.

Teaching at the university context quite often implies the same challenge: grammatical explanations are expected to be given during theoretical classes, in which there are a considerable number of students as opposed to practical classes, in which the students are divided into groups. Therefore, in the English class, teachers have to deal not only with these issues as a starting point but also there are quite a lot of international students, who usually have a higher level of English than Spanish ones. This situation, which obviously should be an advantage and enrichment for the class as a whole, turns out to be a new challenge for teachers 
since foreign students lose interest quickly and tend to skip the grammar class as they think that this class will not teach them anything new.

As a direct consequence of the described situation and circumstances in the grammar class, we assumed it was high time to change our methodology -or at least to modify the patterns in which students have lost their interest- and teach differently in order to achieve quality learning. Long explanations on the board or using PowerPoint presentations before doing exercises seemed to us repeating the same lesson sequence year after year and, definitely, it was time to try another teaching model.

In this sense, the purpose of this article is to show how the flipped approach allowed us to introduce changes in the general class plan. This approach offered significant changes in pre-tasks, task development and class management, which had important consequences on our students' involvement, motivation, performance when working in groups and both teachers and students' roles, as will be shown in different sections of the present article. Besides, we could identify our students' degree of satisfaction with regards to the flipped classroom approach.

This paper aims not only to share our pilot experience in the English classroom following the flipped classroom approach but also to analyse the results of a questionnaire study. The following pages are distributed as follows: a theoretical background is presented to explain the fundamental aspects on which this teaching model focuses. Afterwards, the methodology is described, distributing it into two sections: firstly, the research design is detailed and, secondly, the pilot experience is explained. In a new section, the gathered data of the study are provided and described. Then, some last considerations regarding the pilot experience are discussed. Finally, the limitations and conclusions of the study are drawn.

\section{Theoretical background}

Traditionally, when teaching grammar, the Presentation - Practice - Production (PPP) approach (Larsen-Freeman, 2001, p. 39) is often followed in the grammar class and it is carried out in the following order:

- Presentation: The teacher introduces a grammatical structure in a clear context to show its meaning and form throughout a text, a situation, some questions, a dialogue, etc.

- Practice: Students use the structure in a controlled way.

- Production: Use of the grammatical structure in a more autonomous way.

After reading about and studying the flipped classroom approach, we thought that the previous order of the teaching approach could be used and reorganised in a more motivating way for our students. With the application of the flipped approach, 
the presentation is not done by the teacher since all materials are given to the students previously as a pre-task. So, their previous work consists of reading and/or watching that material and processing it using different techniques such as summarising, taking notes, outlining and finding out more information, among others. As part of the presentation sequence of that material, the students must explain it to their group in class and share the pre-task with their classmates. Practice and production come later by using group work as the main way of this collaborative process. As we will describe later, the teacher monitors at all times as their main role.

When dealing with the flipped classroom approach, it is a must to refer to Benjamin Bloom (1956), who published a framework for categorizing educational goals. The framework consisted of six major categories: Knowledge, Comprehension, Application, Analysis, Synthesis, and Evaluation. In 2001, almost fifty years later, a revision of Bloom's Taxonomy with the title A taxonomy for teaching, learning, and assessment was presented (Anderson \& Krathwohl, 2001). This work draws attention away from the somewhat static notion of «educational objectives» in Bloom's original framework and points to a more dynamic classification.

The authors of the revised taxonomy, aiming to highlight this dynamic conception, use verbs and gerunds to label the six previous categories. Accordingly, these «action words» describe the cognitive processes by which thinkers encounter and work with knowledge. The acquisition of the skills that must be demonstrated in each level or category involves progressing to a higher thinking skill. The correspondence between both taxonomies can be seen in Figure 1 as well as the different levels.

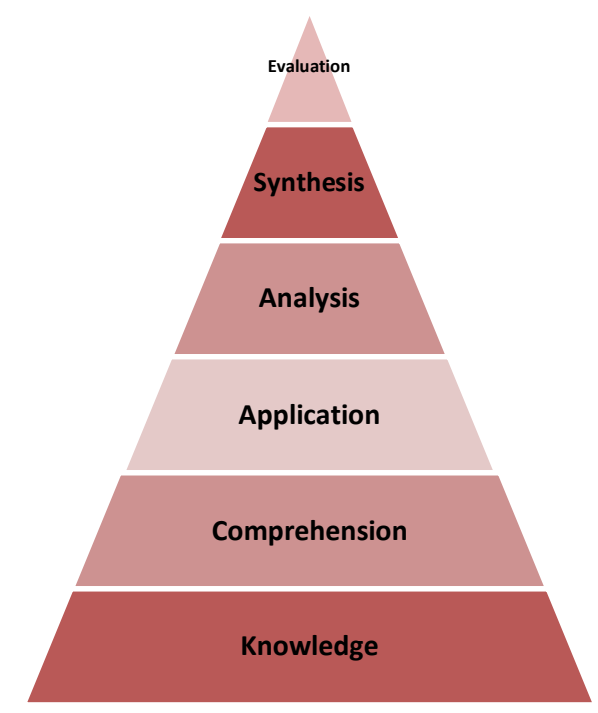

Figure 1:
Bloom's Taxonomy.

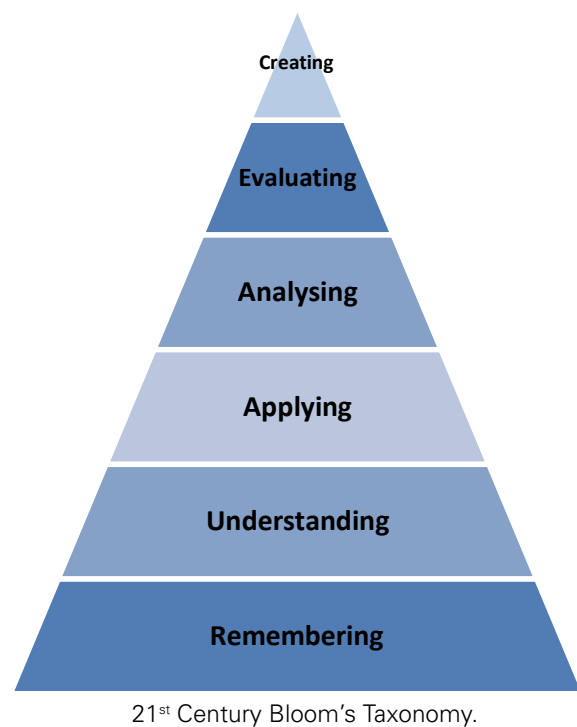

$21^{\text {st }}$ Century Bloom's Taxonomy. 
It is undeniable that the teacher is the main source of knowledge in a traditional teaching approach and students perform as passive actors in the learning process. This means that the lower levels of the cognitive process happen in class; meanwhile, the tasks related to the higher ones are preferred as homework. Nonetheless, when talking about flipping the classroom, class time is devoted to develop and work on tasks which belong to the higher levels of the learning process, such as compare, distinguish, analyse, discuss, decide, predict, imagine, create, etc. On the other hand, students do the activities related to the lower levels at home: finding, listing, labelling, interpreting, completing, describing, solving, among others.

The flipped classroom approach has been used for years in several disciplines, not only Science and Maths, but also Humanities. It has its origins in Woodland Park, a High School in Colorado, where Jonathan Bergmann and Aaron Sams worked together. These teachers, who are widely recognized as flipped classroom pioneers, realised that many of their students did not attend their classes due to extra activities and distance. For that reason, they recorded videos to show and explain to those students the contents so that they could learn without attending their classes (Bergmann \& Sams, 2012, p. 3). Sooner rather than later, they determined that this way of teaching was useful and motivating for their students because they started using the videos to revise contents and prepare their exams.

Although there have been other proposals (Lage, Platt \& Treglia, 2000; Mazur, 2009; Walvoord \& Anderson, 1998), which underline the fact that teaching must be based on students and not on teachers, all of them share two basic ideas. On the one hand, students actively expose to contents at home in different ways: reading the textbook, watching videos, using podcasts, among others. The videos can be created by their teachers or can be found for this purpose on the Internet, which offers a wide range of sources (YouTube, the Khan Academy, etc.). On the other side, the in-class time is used to do tasks related to the contents with which the students have worked previously at home: analysing, synthesizing, discussing and doing activities. In other words, students do activities that belong to the highest level of Bloom's Taxonomy.

Even though the flipped classroom approach has been the focus of numerous studies in recent years, Bueno-Alastuey and Andrés Galar (2017, p. 35) highhlight the fact that there are more publications in disciplines related to science than the teaching of English as a foreign language. Regarding its implementation in the English classroom, some studies (Kvashnina \& Martynko, 2016; Sung, 2015) reveal that the use of the flipped model can increase not only students' motivation but also improve their performance on the course and their autonomous learning skills. Likewise, this pilot study intends to investigate whether students' motivation increases when flipping the grammar classroom, as the aforementioned studies state. 


\section{Methodology}

As this is a small-scale study, it has been considered a pilot one. This section consists of two main subsections. Firstly, the research design of the questionnaire study is explained. Secondly, the pilot experience implementing the flipped approach is detailed, distinguishing the experience in the Degree in Primary Education from that of the Degree in English Studies.

\subsection{Research design}

Several aspects have been considered to design this study following Madrid and Bueno's (2005) guidelines. Thus, it might be said that the framework of this study can be considered applied and practical as it is classroom-based and aims at reflecting on real situations. Besides, the current research is primary because students have provided us with the required data by means of a questionnaire. Likewise, as the intention of this questionnaire is to know our students' opinion about the flipped experience carried out in the classroom, the study can be considered qualitative. Nonetheless, the research can also be regarded as quantitative because the data will be interpreted statistically.

\section{a) Research objectives and questions}

The main motivation to carry out this research was to check whether, on the one hand, the flipped approach was attractive and motivating for students and, on the other, whether it could be effective to teach and learn grammar. For that reason, it was necessary to ask students' opinion after the pilot experience. Even though this study aims to investigate the effectiveness of the flipped classroom approach when teaching grammar, some specific objectives have also been set:

1. To identify our students' degree of satisfaction with regards to the flipped classroom approach after the pilot experience in the classroom.

2. To analyse our students' performance when working in a group.

3. To determine our students' real motivation when doing this task.

With the firm intention of achieving these goals, we will also endeavour to answer the following research questions:

- Do our students prefer the traditional methodology to learn and study Enǵlish grammar?

- Does cooperative learning enhance our students' learning?

- Does the flipped classroom approach improve our students' motivation? 


\section{b) Instruments, variables and data collection}

The instrument used for the collection of data has been a questionnaire consisting of 12 items. To design the questionnaire, Brown's (2001) guidelines were followed; as a result, simple and complete statements have been used in order to facilitate the understanding. Besides, the items are presented in order, grouped according to the aforementioned research questions.

The questionnaire was designed using a five-point Likert scale ranging from 1 to 5, and which is coded as follows: 1: Strongly disagree; 2: Disagree; 3: Neutral; 4: Agree; 5: Strongly agree. As mentioned above, the information was divided into 12 items within the questionnaire and they can be grouped into the following three blocks:

- Block 1: Students' opinion about the flipped classroom approach. (Items 1-5)

- Block 2: Students' opinion about cooperative learning. (Items 6-9)

- Block 3: Students' impression about the experience. (Items 10-12)

Moreover, and as the objective of this research is to determine whether the flipped classroom approach could be appropriate when teaching English grammar, no variables were taken into consideration; in that way, a general overview would be obtained.

Data collection took place one week after having the flipped sessions with our students, exactly in March 2017. The questionnaires were handed in English for the students of the Degree in English Studies and Spanish for the students of the Degree in Primary Education. The participants in this study were 38 students (17 male and 21 female) for Enǵlish Studies Degree and 81 (37 male and 44 female) for Primary Education, which makes a total of 119 participants. As the purpose was to contrast the results in both groups in general, the moderating variable of gender has not been considered in this paper.

\subsection{The pilot experience}

The experience took place in the second semester of the academic year 2016-2017, in particular during the last week of February and the first one of March at the University of Jaén, Spain. It was developed in both the theoretical and practical classes in two different degrees, namely the Degree in English Studies and the Degree in Primary Education. The subjects in which we applied the flipped classroom approach were Instrumental English 3, for students of the third year in the Degree in English Studies and Foreign Language and its Didactics, for students of the second year in the Degree in Primary Education. 
As far as the course of action is concerned, the method was introduced in the same way in both classes:

- First of all, the flipped model was introduced to the students. Therefore, it was stated as clearly as possible, both by email and in the theoretical session, how we intended to work, what we expected from them, what our role, as teachers, was supposed to be and why we wanted to use that particular teaching approach with them in the classroom. It was also stressed that their active participation would be of essential importance because it would mean a part of their final mark.

- Contents to work with: It was also explained in detail what grammar contents were going to be studied and where to find the materials.

- Materials: In the case of the Degree in Primary Education, the grammatical section of the textbook was used as the theoretical material that the students had to prepare and study at home. On the other side, regarding the Degree in English Studies, the materials were provided on the space for the subject of the UJA e-learning platform.

- Timing: Materials were given to the students one week in advance of the application of the teaching model date.

\section{a) The pilot experience in the Degree in Primary Education}

\section{- Pre-task}

In a previous theoretical session, some brainstormed ideas about the new method we were about to apply were first introduced. As the students did not know about it, they showed interest, especially about their roles in this approach. The grammar aspect to revise was that of the future tense in English and the use of will and shall for offers and suggestions. The students were explained that they would have to revise the corresponding grammar at home, and they were told to study the grammar appendix of the textbook used: English File. Intermediate (Latham-Koenig \& Oxenden, 2013). They were asked to read, study and revise this grammar part before the practical class to be ready to explain it to their group. Nevertheless, it is noteworthy that most of them were already familiarized with the uses of the future tense as well as the use of will and shall to express offers and suggestions.

\section{Task development}

The next sessions were carried out during the time devoted to practical classes and the method was applied by four different groups (A, B, C and D); as a result, this part was done on four occasions. A summary of the common aspects that happened in class will be offered and also the differences among the groups 
will be mentioned. While the students were entering the classroom, a very short grammar reminder was written on the board, closer to an outline, as Table 1 shows, so that they could have it as a help to organize their ideas. However, this was not formal teaching or a traditional grammar class, in which the teacher revises in detail the contents with the students.

Table 1. Grammar reminder

\begin{tabular}{llc}
\multicolumn{1}{c}{ Future forms } & \multicolumn{1}{c}{ Offers } & \multicolumn{1}{c}{ Suggestions } \\
Be going to & I'll carry that bag for you & Shall we eat out tonight? \\
Present continuous & Shall I help you? & \\
Will & &
\end{tabular}

Class management

The students were divided into groups of three or four members and were explained that they could have on their desks their outlines, notes, and the grammar appendix to consult. The idea of a class exercise was emphasized to make them understand that the experience was not an exam. Although the students were encouraged to speak in English as much as possible, they were allowed to use Spanish occasionally since their English average level was intermediate.

- Class Development

In the beginning, the students' hesitation could be observed. This was their first time working with the method and they did not feel totally at ease. For that reason, they were encouraged to share their information about the grammar point and to tell their classmates all they knew about it. What happened in all groups was that there was always one student who participated more actively and with more confidence. However, little by little the rest of the members also shared their grammar explanations. In some groups, some of the students were honest and told the rest that they had not done the previous task of revising the grammatical contents.

The teacher's role at that time was that of monitoring groups. It could be observed that the main way in which the groups shared their points was by making questions to each other. They also worked by taking notes and outlining; besides, some of them completed those notes that they had previously taken at home.

What is remarkable at that stage was that as the task developed, the students felt more confident and interacted more often with their classmates. The groups 
were more concentrated on the task. The type of help they asked the teacher was less demanding at that moment, and their doubts had to do more with nuances in the use of the grammar tense, and not with fundamental differences in the types of future. In the final part of the class, the groups could solve doubts with little intervention on the teacher's part or even without any help and they did some exercises together.

\section{The final part of the class}

As a final part of the task in class, the students were asked to complete some exercises. In the last twenty minutes of the class, the students had not completed their task of doing all of them, but they felt satisfied because their work up to that moment had been the result of the group's work. They were proposed to revise the exercises all together in the next class. The group as a whole was congratulated for their work and participation, and some groups clapped spontaneously. All the students were given a mark for their class participation.

- The teacher's role

After repeating the class with the four different groups, the fact that the teacher is constantly required for help is worth mentioning. When the class started, the students were not really conscious that a flipped approach was about to be applied, and they presupposed that it is the teacher who had to provide explanations and solve all problems. Consequently, the teacher tried to avoid assuming this role all time and monitored their process solving some little problems. Instead of offering grammar explanations, the students were guided by eliciting some key questions for the grammatical point, such as «look at this sentence. Can I use 'present continuous' and 'be going to' without any change in meaning?» or «what does the context suggest here? Is the speaker expressing his/her intention for doing something», has s/he planned the action beforehand?» Therefore, the students were encouraged to solve their doubts by deducing answers and paying attention to the examples provided in the textbook. At this point, the teacher turned out to be a close guidance figure who stayed close to the groups and monitored the students' deductions to be sure they were doing it right.

On the whole, one important aspect that can be remarked concerning the teacher's role is that when the group had a low level in grammar or their use of English, they demanded the teacher constantly. It was hard for the teacher to show them that with the flipped approach more previous work on their part was required. In this sense, they felt less motivated with the class development since they understood the teacher was not «helping» them in the way they wanted. They were more demanding, less autonomous and reluctant to change from the 
traditional explanation of grammar by the teacher. As a final note, it can be mentioned that in all sessions a working atmosphere was created successfully and there was no disturbing background noise.

\section{b) The pilot experience in the Degree in English Studies}

- Pre-task

In a previous session, students were asked to organise themselves into groups of four members and the different steps that would be followed to complete the task were also explained. The grammatical topic related to the activity was relative clauses and the students had to prepare it at home to be able to complete it in class with the rest of the group. First of all, the students were asked to watch a video (Ms EOI Teacher, 2014) about this theme, previously found in the video-sharing website YouTube, and they were also asked to read a pdf file prepared following the Oxford guide to English grammar (Eastwood, 2002).

While the students were reading the document or watching the video, they had to take their own notes with the most important ideas and aspects about relative clauses in English because, later, in the classroom, they had to be ready not only to explain them to the rest of the group but also to debate and decide about which aspects of relative clauses should be included in the design of a poster.

\section{Class management}

The first thing to do was to organise the different groups in the classroom. Meanwhile designing the activity, the idea that the organisation of the groups in the classroom might be chaotic was contemplated; however, it was easier than thought. On the other hand, it is worth mentioning that it was a bit uncomfortable for the students to work in groups due to the design of the classroom. It would have been perfect to have worked in a classroom with the possibility of moving desks and chairs. Nonetheless, this little inconvenience did not negatively affect the development of the flipped experience.

- Class Development

The different groups started working and the students initiated a debate session, discussing what they had learnt watching the video and reading the document with the grammatical contents. They had to decide which aspects were the most important ones and which ones should be included in the poster that they had to make as a project. They also thought about their own original examples to illustrate their ideas. The different groups were continually monitored by the teacher who checked if they had any doubts to be explained. Besides, some adjustments were made when necessary to solve their errors and /or possible misunderstanding. 
Remarkably, most students prepared their work beforehand; however, it should also be mentioned that only two groups did not do their homework. Although they gave their reasons why they had not done the previous task, this fact entailed a series of consequences in the dynamics of the activity in the classroom. Therefore, these two groups had to start reading the document in the classroom and they did not have enough time to finish the whole task.

After discussing the main points of relative clauses, the next step was to design a poster. Not only did the students have to decide and organise the different aspects to include in the poster but also they had to consider all the issues regarding the design they wanted to follow. Most of them use software like Microsoft PowerPoint to create their poster.

In this stage of the activity, the teacher's role consisted of scaffolding the activity to make it accessible to every group. For that reason, collaboration with them was completely necessary to provide relevant feedback and assess their work. Most of the groups could start with the design of the poster during class time and some of them even finished it and submitted their project. On the other hand, the rest of the students who did not complete the poster during the sessions had one week to finish it before the deadline and they had to do it as homework.

The learning environment in the classroom was excellent; surprisingly, there was no noise in excess or annoying. Likewise, each group worked in a very collaborative way and all of them seemed to be motivated.

\section{Data analysis and findings}

The data analysis has been performed by using the IBM SPSS program in its 21.0 version. Apart from dealing with the statistical analysis, this software allowed us to calculate the internal reliability of the instrument used in the study according to Cronbach's Alpha. As shown in Table 2, the reliability can be considered within a good range.

Table 2. Cronbach's Alpha

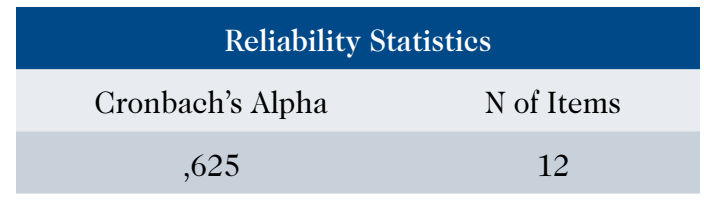

In this section, the results will be presented using pie charts in order to show them clearly and precisely. The results in case A) correspond to the Degree in Eng- 
lish Studies while those in case B) coincide with the Degree in Primary Education. Moreover, the responses given by the participants will be divided into the three different blocks described previously in which the twelve items can be grouped:

\subsection{Block 1: Students' opinion about the flipped approach}

Item 1: I prefer the traditional way to study grammar.

A) English Studies

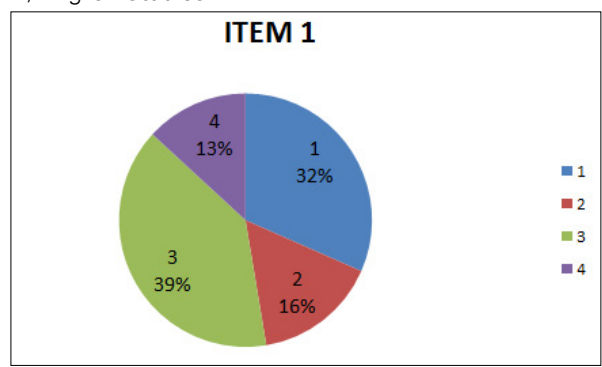

B) Primary Education

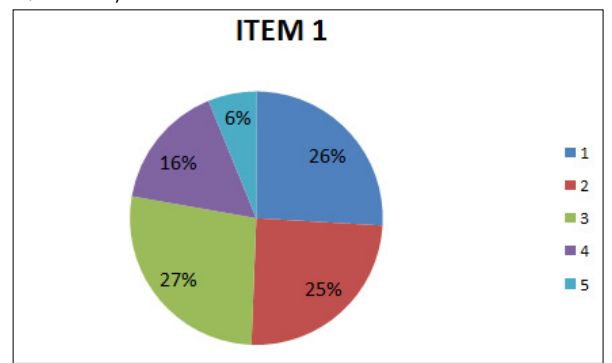

Figure 2: Item 1 Frequency Distribution.

As Figure 2 shows, in A) nobody prefers the traditional method because the option 5 (strongly agree) on the scale was not selected. Consequently, it can be stated that the great majority (48\%) prefers this flipped method. Likewise, in B) - analogous results are obtained - although $22 \%$ is for the traditional way of teaching grammar.

Item 2: I think this learning model is more useful than the traditional one.

A) English Studies

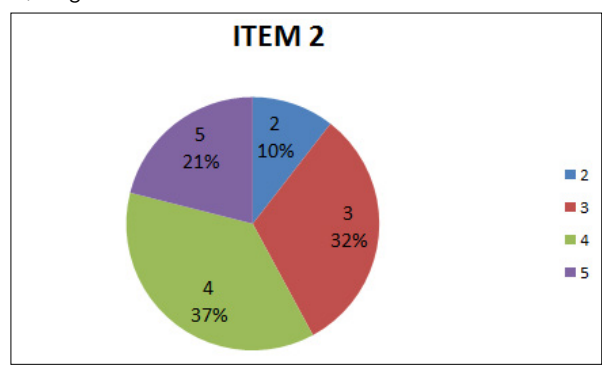

Figure 3: Item 2 Frequency Distribution.
B) Primary Education

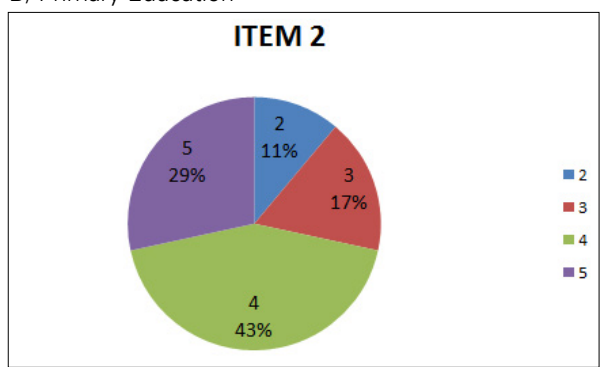

As indicated in Figure 3, in case A) the great majority values the usefulness of this method. $37 \%$ of the participants agree and $21 \%$ strongly agree with the 
usefulness of this approach. Similarly, in B) the results are comparable because $72 \%$ of the students are in favour of this model.

Item 3: I think this learning model motivates students.

A) English Studies

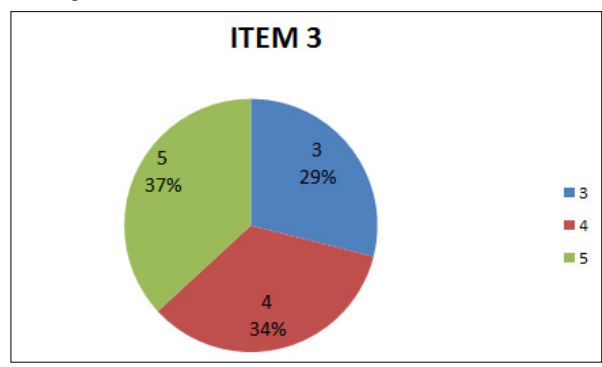

Figure 4: Item 3 Frequency Distribution.
B) Primary Education

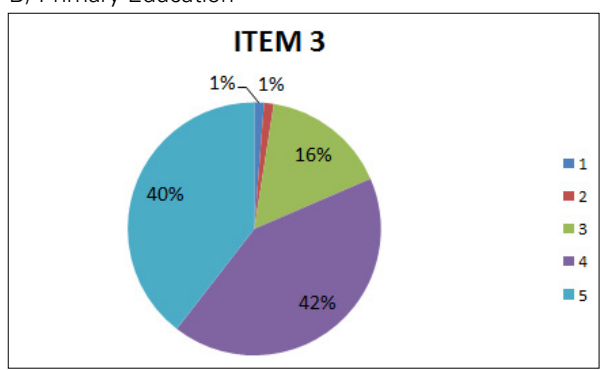

Item 3 is related to motivation and Figure 4 indicates that in both Degrees students think that this model is a motivating way of learning grammar. On the other hand, it can be observed that whereas no students choose options 1 and 2 in case A), only $2 \%$ of them state the contrary in B).

Item 4: I think this approach encourages critical learning.

A) English Studies

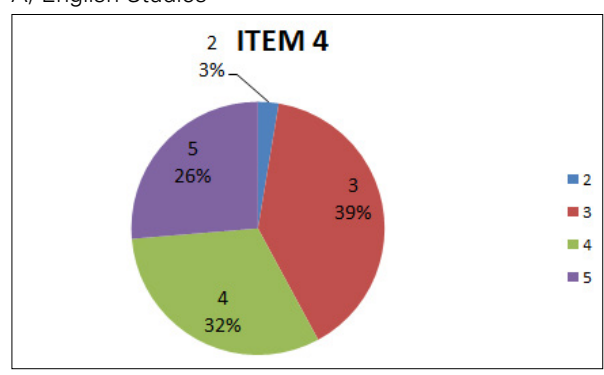

Figure 5: Item 4 Frequency Distribution.
B) Primary Education

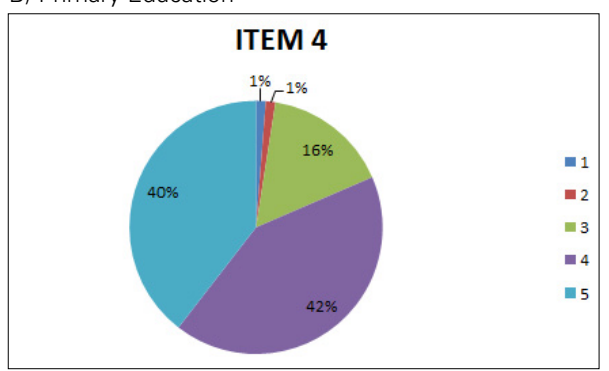

Regarding critical learning, in both Degrees students associate this methodology with it. As can be seen, in case A) $32 \%$ agree with this statement and $26 \%$ strongly agree. Only $2 \%$ show disagreement with it. In the case of B), on the other hand, the percentage of students who agree or strongly agree is higher, making $82 \%$ of them. However, it is very significant that $39 \%$ remain neutral in the Degree in English Studies whereas this option is only chosen by $16 \%$ of the students belonging to the Degree in Primary Education. 
Item 5: I think I have learnt a lot about relative clauses / future tenses.

A) English Studies

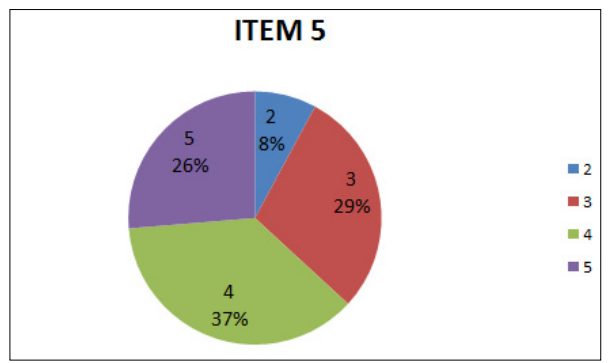

Figure 6: Item 5 Frequency Distribution.
B) Primary Education

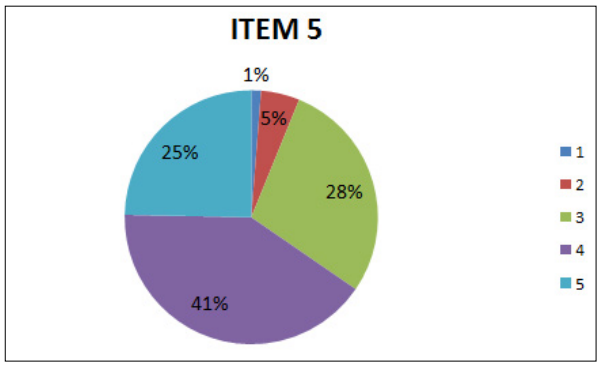

On the basis of an assessment of responses, none of the students strongly disagree with the statement in case $\mathrm{A}$ ), and only 8\% disagree. Options 1 and 2 are only elected by the $6 \%$ of the participants in case B). Nonetheless, it can be claimed that in both cases our students are aware of their own learning and they state it [63\% in case A) and $66 \%$ in case B)].

\subsection{Block 2: Students' opinion about cooperative learning}

Item 6: I think working in groups is a useful way to learn from one another.

A) English Studies

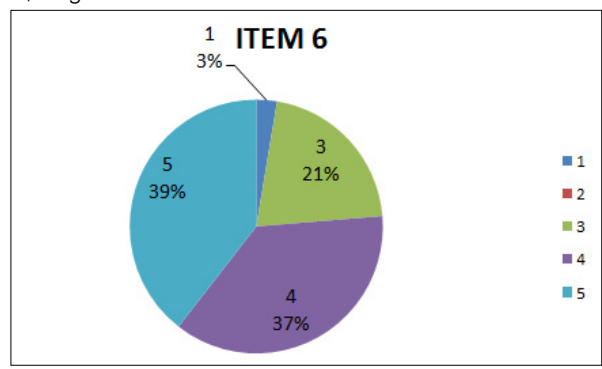

Figure 7: Item 6 Frequency Distribution.
B) Primary Education

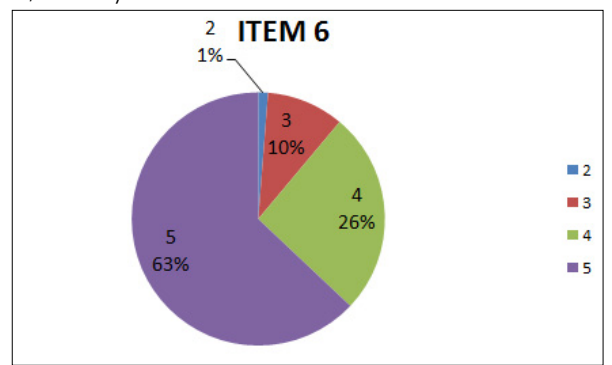

In both cases, students highly value the importance of group work as it is shown in both pie charts. Many participants agree [37\% in case A) and $26 \%$ in B)] with the statement and $39 \%$ strongly agree in case A). In contrast, in the case of B), it is noteworthy the $63 \%$ of students show themselves enthusiastic about it. 
Item 7: Working in groups involves accepting others' ideas to reach an agreement.

A) English Studies

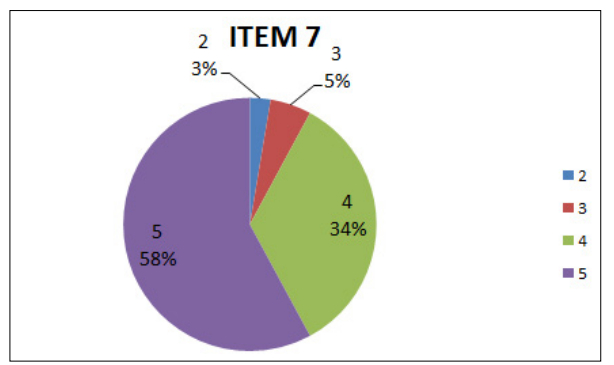

Figure 8: Item 7 Frequency Distribution.
B) Primary Education

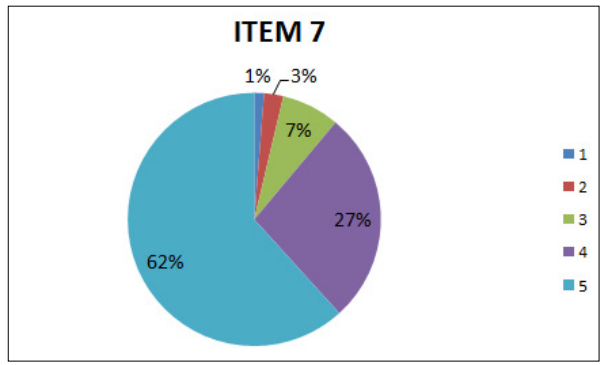

In cooperative learning, it is crucial to reach an agreement to continue learning and working; for that reason, we asked our students whether they agree with this concept. As a matter of fact, in both Degrees students admit that it is essential to accept the other members' opinions when working in a group. $58 \%$ in case A) and $62 \%$ in case B) strongly agree with this idea.

Item 8: I think some members of my group haven't worked very hard.

A) English Studies

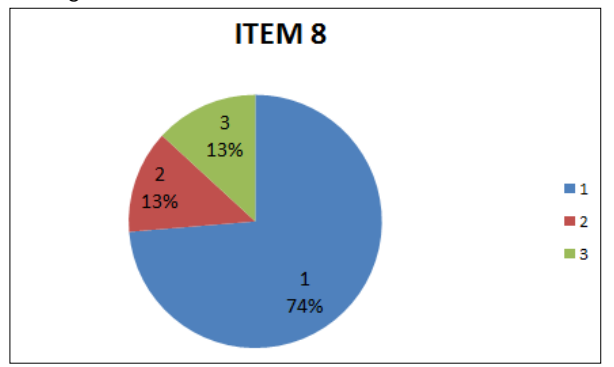

Figure 9: Item 8 Frequency Distribution.
B) Primary Education

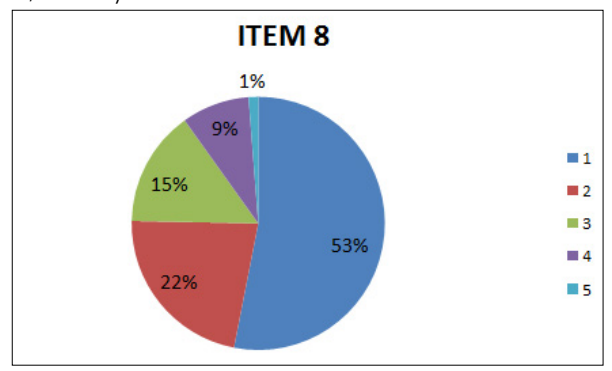

On the basis of an assessment of responses about the degree of involvement when working in a group, in both cases the majority of the students [74\% in case A) and 53\% in case B)] have a positive perception of their classmates' work. Likewise, it is very significant that none of the participants in case A) agree or strongly agree with this statement. However, 9\% agree and 1\% strongly agrees with it in case B).

Concerning the percentage of students who show neutrality, the results in both cases are analogous. The $13 \%$ who are undecided in case A) almost equate with $15 \%$ of the students in case B) who remain neutral. 
Item 9: I prefer working on my own.

A) English Studies

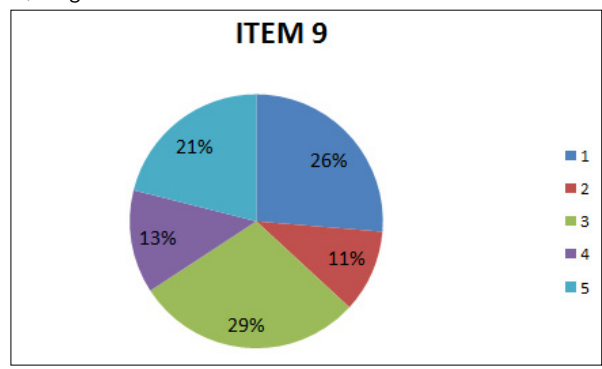

Figure 10: Item 9 Frequency Distribution.
B) Primary Education

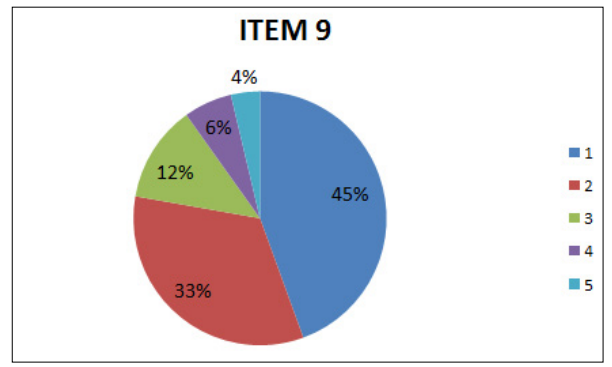

As the pie charts determine, the students participating in the survey distinctly prefer working in groups. This fact is more evident in case B) than in A) because $45 \%$ strongly disagree and $33 \%$ disagree with the statement. On the other hand, in case A), in which the significant $29 \%$ of students do not show their preference for group working clearly, only $11 \%$ agree and the $26 \%$ of the participants strongly disagree with the assertion.

\subsection{Block 3: Students' impression about the experience}

Item 10: In my opinion, the main aim of this activity is the possibility of getting a good mark.

A) English Studies

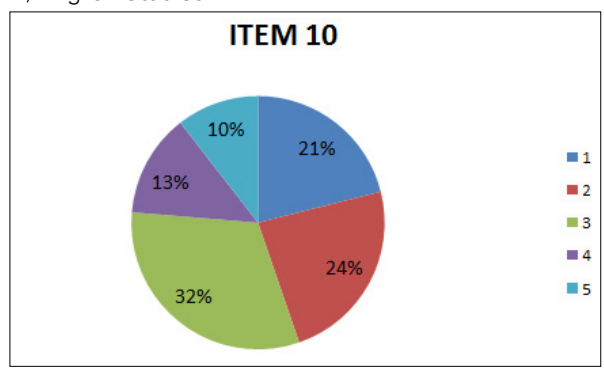

Figure 11: Item 10 Frequency Distribution.
B) Primary Education

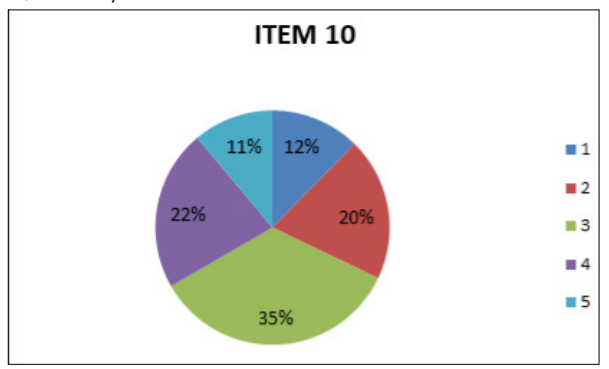

The results of this item reflect the students' diverse opinion. On the one hand, the participants of the Degree in English Studies Degree specify their disagreement with the statement (46\%) and only $23 \%$ show in accordance with the assertion. On the other one, the students of the Degree in Primary Education expose more equality in their options: $32 \%$ show disagreement and $33 \%$ agreement. 
It is remarkable that in both cases the results are very similar when talking about neutrality: $32 \%$ in case A) and $35 \%$ in case B).

Item 11: I have enjoyed this experience.

A) English Studies

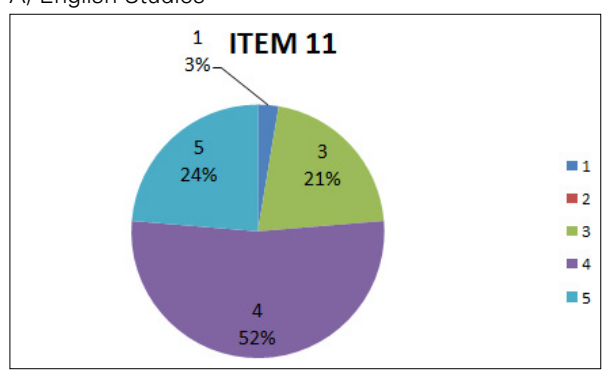

Figure 12: Item 11 Frequency Distribution.

\section{B) Primary Education}

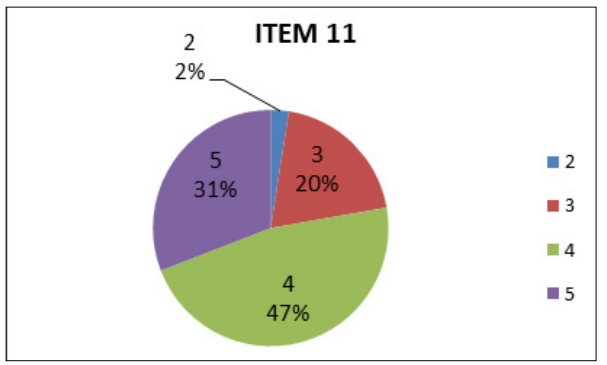

In terms of the degree of satisfaction, both groups seem to have enjoyed the flipped classroom experience. The results in both cases are actually similar: $76 \%$ show agreement in case A) and $78 \%$ in B). Likewise, the percentages of participants who remain neutral in their responses [21\% in case A) and $20 \%$ in case B)] are analogous.

Item 12: I will definitely repeat more activities like this one.

A) English Studies

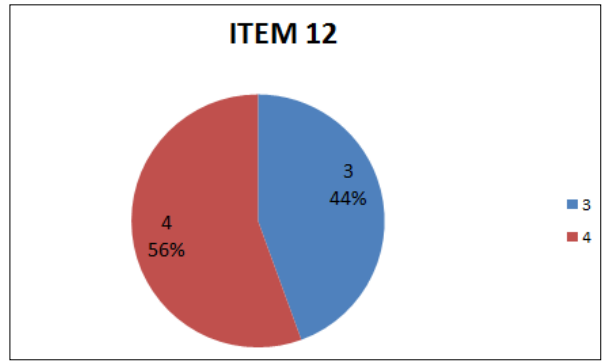

Figure 13: Item 12 Frequency Distribution.
B) Primary Education

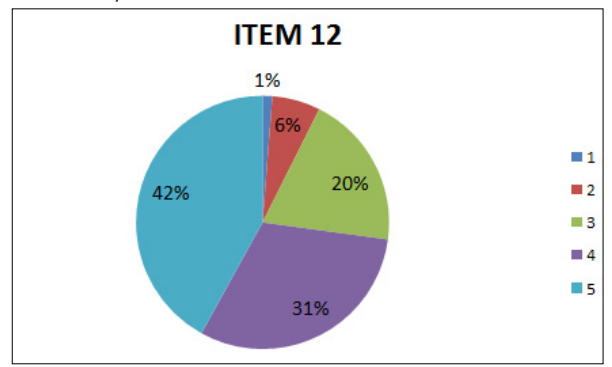

Regarding the repetition of more activities within the flipped classroom approach, the vast majority of our students manifests their approval with this kind of activities. Although neutrality is more observable (44\%) in case A) than in B) with only $20 \%$, none of the students of English Studies states their discrepancy with more experiences like this one. 
As far as descriptive statistics is concerned, Table 3 shows a general overview of the whole sample, including central tendency measures such as the mean and dispersion ones such as standard deviation.

Table 3. Descriptive statistics

\begin{tabular}{|c|c|c|c|c|c|c|c|c|c|c|c|c|c|}
\hline \multicolumn{2}{|c|}{ Item } & 1 & 2 & 3 & 4 & 5 & 6 & 7 & 8 & 9 & 10 & 11 & 12 \\
\hline \multirow[t]{2}{*}{$\mathrm{N}$} & Valid & 119 & 119 & 119 & 119 & 119 & 119 & 119 & 119 & 119 & 119 & 119 & 119 \\
\hline & Missing & 0 & 0 & 0 & 0 & 0 & 0 & 0 & 0 & 0 & 0 & 0 & 0 \\
\hline Mean & & 2,46 & 3,82 & 4,14 & 4,06 & 3,82 & 4,38 & 4,46 & 1,69 & 2,24 & 3,62 & 3,30 & 4,03 \\
\hline Median & & 3,00 & 4,00 & 4,00 & 4,00 & 4,00 & 5,00 & 5,00 & 1,00 & 2,00 & 4,00 & 3,00 & 4,00 \\
\hline Mode & & 3 & 4 & 4 & 4 & 4 & 5 & 5 & 1 & 1 & 4 & 4 & 5 \\
\hline $\begin{array}{l}\text { Std. } \\
\text { Deviation }\end{array}$ & & 1,170 & ,945 & ,826 & ,857 & ,908 & ,813 & ,800 & ,981 & 1,300 & 1,150 & 1,161 & ,929 \\
\hline Variance & & 1,369 & ,892 & ,683 & ,734 & ,825 & ,661 & ,641 & ,962 & 1,690 & 1,322 & 1,348 & ,863 \\
\hline Minimum & & 1 & 2 & 1 & 1 & 1 & 1 & 1 & 1 & 1 & 1 & 1 & 1 \\
\hline Maximum & & 5 & 5 & 5 & 5 & 5 & 5 & 5 & 5 & 5 & 5 & 5 & 5 \\
\hline \multirow[t]{5}{*}{ Percentiles } & 5 & 1,00 & 2,00 & 3,00 & 3,00 & 2,00 & 3,00 & 3,00 & 1,00 & 1,00 & 1,00 & 1,00 & 2,00 \\
\hline & 25 & 1,00 & 3,00 & 4,00 & 3,00 & 3,00 & 4,00 & 4,00 & 1,00 & 1,00 & 3,00 & 3,00 & 3,00 \\
\hline & 50 & 3,00 & 4,00 & 4,00 & 4,00 & 4,00 & 5,00 & 5,00 & 1,00 & 2,00 & 4,00 & 3,00 & 4,00 \\
\hline & 75 & 3,00 & 5,00 & 5,00 & 5,00 & 5,00 & 5,00 & 5,00 & 2,00 & 3,00 & 4,00 & 4,00 & 5,00 \\
\hline & 95 & 4,00 & 5,00 & 5,00 & 5,00 & 5,00 & 5,00 & 5,00 & 4,00 & 5,00 & 5,00 & 5,00 & 5,00 \\
\hline
\end{tabular}

\section{Final considerations about the Flipped experience}

Most teaching sequences need to have certain elements, whether they take place over a few minutes, half an hour, a lesson or a sequence of lessons. According to Harmer $(2007$, p. 51), these elements are Engage, Study and Activation (ESA). The application order for these elements can be chosen by the teacher to get the most adequate way for classroom development. When flipping the classroom these elements proposed by Hammer are also present and they can be applied in a simple and motivating way for the students. As it is a student-centred approach, the students are an active part in every moment. The ESA sequence order in our flipped classroom was the following:

Engagement: Motivation was present in the whole process since the students played an active role by processing the materials we gave them, explaining them to his/her classmates, doing exercises and a final poster together. Part of the moti- 
vation was due to the incentive of being given a mark for their collaborative work. It is noteworthy that doing the task differently was an encouragement for them, and consequently, they got involved much more than when grammar is explained in a more traditional way.

Study: This part was carried out by the students previously, facilitating their independence and initiative to make them focused on the material given in advance in a personal manner. It was completed by their collaborative work in groups and developed in the activation step carried out later in class.

Activation: In the practical classes the students had the opportunity to activate the grammatical points by sharing their explanations and outlines, doing grammatical exercises and a poster together. In their process of activation, the students used language as freely and communicatively as they could, which was a motivating factor for them.

Therefore, it is worth mentioning that not only could we apply the elements of the ESA sequence from a motivating point of view in our flipped classroom, but also that the four fundamental pillars (Flipped Learning Network, 2014) of this approach were successfully present.

\section{F (Flexible Environment)}

Unfortunately, it was not possible to rearrange the classroom physically since the furniture was fixed. Nevertheless, the groups were rearranged within the space and the students could work reasonably comfortable.

\section{$L$ (Learning Culture)}

During this flipped experience, the teachers were not the primary source of information. Thanks to students' previous work at home, the in-class time was dedicated to discussing, analysing, reasoning, and learning from one each other. As a result, the students were actively involved in their learning process.

\section{I (Intentional Content)}

It was determined what to teach and what type of materials students should discover own their own. As a consequence, the in-class time was focused on active learning strategies.

\section{$P$ (Professional Educator)}

During the sessions, we became more accessible teachers because we were available to all the students for individual and small groups. Besides, class feedback in real-time was provided as needed.

As the study of the questionnaire reveals, the students felt motivated during the flipped experience, stating that the flipped classroom approach can be a good way of learning English grammar. Likewise, they showed a positive evaluation of 
this model. It is also worth mentioning that a significant majority think that cooperative work can be advantageous for them.

On the whole, the general assessment for the application of this teaching model is very positive because all groups worked well and dynamically, getting involved in the experience. Therefore, offering grammar from this active perspective meant a more direct implication by the students and the possibility for them of being more thoughtful with the grammar component. Besides, it should be mentioned that when the students were asked to revise the grammatical contents at home so that they could explain it later to their group, they got involved more deeply in the task and were willing to do the assignment.

The objective of presenting a teaching model that is motivating for students and can be effective to teach English grammar has been fulfilled in this pilot experience. As mentioned above, the vast majority of students were committed to the activity and responded by working actively.

\section{Limitations and further research}

Some limitations of the present research should be highlighted. Firstly, the number of participants in the Degree in English Studies was not very representative. Although many more students were involved in the flipped classroom experience, only thirty-eight became participants in this pilot study. Therefore, the results of both groups can be contrasted and compared but are not analogous according to the number of participants for each group.

Secondly, as this study has been based on a questionnaire designed by the researchers, it may present some restrictions. Thus, this instrument of data collection may fail to designate all the reasons which actually influence the conclusions. Thirdly, we are aware of the fact that more flipped learning activities would have offered students' different opinions and results. Researching more grammar contents within a longer period could lead to significant findings.

As a matter of fact, further research with a bigger sample and a more complete survey could be very interesting. Likewise, a future study distinguishing between male and female participants could also show noteworthy results.

\section{Conclusions}

Working with the flipped classroom approach led us to reflect upon some risks and trials within the classroom, which could affect the general class development. First of all, when the members of the group have a low level of spoken English, they tend to speak in Spanish and feel less confident with the pre-task 
they have done previously. This is why they show less autonomy and depend much more on the teacher's intervention. Consequently, they demand a more traditional teacher's role, in which the teacher provides them with grammar explanations and solves all their doubts.

Secondly, all students should participate equally in an ideal application of the method. In this sense, our students themselves reflected and pointed to the idea of the need for all the group members to have studied and worked the material previously. If this is not the case, the situation would be that one or two students would play the role of teacher for the rest of the group. Therefore, the students who have not done the previous task would settle in their passive role of listeners and would spend the class copying other member's outlines and activities, which is far from the original idea of the approach.

Thirdly, another possible problem is assuming that all students have understood the concepts that they have previously worked on. We found that some of the students with a lower level of English tended to hide that 'they did not know enough'. In their belief, they tended to keep aside and let other students have a more active role since they thought that their intervention was not going to be interesting enough for the rest of the group.

As a final consideration, we will stress the teacher's role as a motivator. Part of this motivation comes from a thorough explanation of the approach to the students. Besides, teachers should be persuaded of the success of implementing the model so that they could convince their students about the fact that learners can benefit actively since it is a student-centred approach. In this sense, it was essential to point the students out that their work in class would be part of their final mark in the subject.

If students need not only motivation but exposure to language and opportunities for language use to get their language goals, it can be confirmed that our students have had all these three elements with the application of the flipped classroom approach.

Finally, and as far as the accomplishment of the research objectives is concerned, it should be mentioned that the two main targets of this pilot study were first to check the students' motivation when exposed to the flipped approach, and second, whether this approach proved effective when teaching and learning English grammar. So, after applying the approach and evaluating the questionnaire results, it can be concluded that a change in the teaching model, from a more traditional one to the flipped classroom approach, meant a higher level of motivation on the part of the students'. Moreover, it can be affirmed that not only did the students feel more enthusiastic about their task but also they showed competence in cooperative learning. In this sense, the approach can be highly efficient whenever the pre-task is carried out by all the members in the group and when the learners feel confident. As a result, they act as an active part of their learning process within the flipped classroom approach. 


\section{References}

Anderson, L.W. \& Krathwohl, D. (2001). A taxonomy for learning, teaching, and assessing: A revision of Bloom's taxonomy of educational objectives. New York: Longman.

Bergmann, J. \& Sams, A. (2012). Flip your classroom: Reach every student in every class every day. Washington DC: International Society for Technology in Education.

Bloom, B. S. (Ed.). (1956). Taxonomy of educational objectives. New York: David McKay Company Inc.si.

Brown, J. D. (2001). Using surveys in language programs. Cambridge: Cambridge University Press.

Bueno-Alastuey, M. C. \& Andrés Galar, I. (2017). Flipping the EFL classroom in a secondary education setting: Students' perceptions and academic performance. Huarte de San Juan. Filología y Didáctica de la Lengua, 17, 2017, 35-57.

Eastwood, J. (2002). Oxford guide to English grammar. Oxford: Oxford University Press.

Flipped Learning Network. (2014). The four pillars of F-L-I-PTM. Flipped Learning Network. (FLN). Retrieved from http://flippedlearning.org/cms/lib07/VA01923112/ Centricity/Domain/46/FLIP_handout_FNL_Web.pdf

Harmer, J. (2007). How to teach English. Harlow: Pearson Education.

Kvashnina, O. S. \& Martynko, E. A. (2016). Analyzing the potential of flipped classroom in ESL teaching. International Journal of Emerging Technologies in Learning (IJET), 11(03), 71-73.

Lage, M. J., Platt, G. J. \& Treglia, M. (2000). Inverting the classroom: A gateway to creating an inclusive learning environment. The Journal of Economic Education, $31,30-43$.

Larsen-Freeman, D. (2001). Grammar. In R. Carter \& D. Nunan (Eds.), The Cambridge guide to teaching English to speakers of other languages (pp. 34-41). Cambridge: Cambridge University Press.

Latham-Koenig, Ch. \& Oxenden, Cl. (2013). English file. Intermediate. Oxford: Oxford University Press.

Madrid, D. \& Bueno, A. (2005). Glassroom research. In N. McLaren, D. Madrid \& A. Bueno, TEFL in Secondary Education (pp. 646-647). Granada: Editorial Universidad de Granada.

Mazur, E. (2009). Farewell, lecture? Science, 323, 50-51.

Ms EOI Teacher (2014, November 29). Relative clauses. [Video file]. Retrieved from https://youtu.be/kv1NSyyDT-M

Sung, K. (2015). A case study on a flipped classroom in an EFL content course. Multimedia-Assisted Language Learning, 18(2), 159-187.

Walvoord, B. E. \& Anderson, V. J. (1998). Effective grading: A tool for learning and assessment. San Francisco: Jossey-Bass. 
